\section{REFERENCES}

1. Abrutyn EA, Talbot GH. Surveillance strategies: a primer. Infect Control 1987;8:459-464.

2. Brachman PS. Nosocomial infections surveillance. Infect Control Hosp Epidemiol 1993;14:194-196.

3. Emmerson M. Surveillance strategies for nosocomial infections. Curr Opin Infect Dis 1995;8:272-274.

4. Pottinger JM, Herwaldt LA, Perl TM. Basics of surveillance-an overview. Infect Control Hosp Epidemiol 1997;18:513-527.

5. Roy M-C, Perl TM. Basics of surgical-site infection surveillance. Infect Control Hosp Epidemiol 1997;18:659-668.

6. Gaynes R, Horan T. Surveillance of nosocomial infections. In: Mayhall CG, ed. Hospital Epidemiology and Infection Control. Philadelphia, PA: Williams \& Wilkins; 1997.

7. French GL, Wong SL, Cheng AFB, Donnan S. Repeated prevalence surveys for monitoring effectiveness of hospital infection control. Lancet 1989;28:1021-1023.

8. Weinstein J, Mazon D, Pantelick E, Reagan-Cirincione P, Dembry L, Hierholzer W. A decade of prevalence surveys in a tertiary-care center: trends in nosocomial infection rates, device utilization, and patient acuity. Infect Control Hosp Epidemiol 1999;20:543-548.

9. Garner JS, Emori WR, Horan TC, Hughes JM. CDC definitions for nosocomial infections. Am I Infect Control 1988;16:128-140.

10. Horan TC, Gaynes RP, Martone WJ, Jarvis WR, Emori TG. CDC definitions of surgical site infections: a modification of CDC definitions of surgical wound infections. Infect Control Hosp Epidemiol 1992;13:606-608.

11. Gastmeier P, Kampf G, Wischnewski N, Hauer T, Schulgen G, Schumacher $M$, et al. Prevalence of nosocomial infections in representatively selected German hospitals. J Hosp Infect 1998;38:37-49.

12. Gastmeier P, Sohr D, Rath A, Forster D, Wischnewski N, Lacour M, et al. Repeated prevalence investigations on nosocomial infections for continuous surveillance. I Hosp Infect. In press.
13. Emori TG, Culver DH, Horan TC, Jarvis WR, White JW, Olson DR, et al. National nosocomial infection surveillance system (NNIS): description of surveillance methodology. Am I Infect Control 1991;19:19-35.

14. Culver D. Methods of comparing nosocomial infection rates. In: Program and Abstracts of the Sixth Annual Scientific Meeting for the Society of Healthcare Epidemiology of America. April 21-23, 1996; Washington, DC.

15. Civetta J, Hudson-Civetta J, Ball S. Decreasing catheter-related infection and hospital costs by continuous quality improvement. Crit Care Med $1996 ; 24: 1660-1665$.

16. Dumigan D, Kohan C, Fikrig M, Reed C. Utilizing National Nosocomial Infection System Data to improve urinary tract infection rates and catheter utilization in three intensive care units. Association of Practitioners in Infection Control 24th Annual Educational Conference and International Meeting. New Orleans, LA. Am I Infect Control 1998;25:168.

17. Kelleghan SI, Salemi C, Padilla S, McCord M, Mermilliod G, Canola T, et al. An effective continuous quality improvement approach to the prevention of ventilator-associated pneumonia. Am J Infect Control 1993;21:322-330.

18. Beck-Sague C, Jarvis WR, Martone WJ. Outbreak investigations. Infect Control Hosp Epidemiol 1997;18:138-145.

19. Jarvis W, Zaza S. Investigation of outbreaks. In: Mayhall CG, ed. Hospital Epidemiology and Infection Control. Philadelphia, PA: Lippincott Williams \& Wilkins; 1999:111-120.

20. Glenister HM, Taylor LJ, Bartlett CLR, Cooke EM, Sedgwick JA, Mackintosk CA An evaluation of surveillance methods for detecting infections in hospital inpatients. I Hosp Infect 1993;23:229-242.

21. Evans RS, Larsen RA, Burke JP, Gardner R, Meier FA, Jacobson JA, et al. Computer surveillance of hospital acquired infections and antibiotic use. JAMA 1986;256:1007-1011.

22. Teare ET, Peacock A. The development of an infection control nurse program in a district hospital. J Hosp Infect 1996;34:267-278.

\title{
Management of Ventilator-Associated Pneumonia
}

\section{Gina Pugliese, RN, MS Martin S. Favero, PhD}

Optimal management of patients who are clinically suspected of having ventilator-associated pneumonia (VAP) remains open to debate. Fagon and coinvestigators from Hôpital Broussais, Paris, France, conducted a study to evaluate the effect on clinical outcome and antibiotic use of two strategies to diagnose VAP and select initial treatment for this condition. The study was a multicenter, randomized, uncontrolled trial in 31 ICUs in France and included 413 patients suspected of having VAP. The invasive management strategy was based on direct examination of bronchoscopic protected specimen brush samples or bronchoalveolar lavage samples and their quantitative cultures. The noninvasive (clinical) management strategy was based on clinical criteria, isolation of microorganisms by nonquantitative analysis of endotracheal aspirates, and clinical practice guidelines. Measurements were death from any cause, quantification of organ failure, and antibiotic use at 14 and 28 days.

Compared with patients who received clinical management, patients who received invasive management had reduced mortality at day 14 , decreased mean Sepsis-Related Organ Failure Assessment scores at day 3 and day 7, and decreased antibiotic use (mean number of antibiotic-free days). At 28 days, the invasive management group had significantly more antibiotic-free days, and only multivariate analysis showed a significant difference in mortality.

Compared with a noninvasive management strategy, an invasive management strategy was significantly associated with fewer deaths at 14 days, earlier attenuation of organ dysfunction, and less antibiotic use in patients suspected of having VAP.

FROM: Fagon JY, Chastre J, Wolff M. Gervais C, Parer-Aubas S, Stephan F, et al. Invasive and noninvasive strategies for management of suspected ventilatorassociated pneumonia. A randomized trial. Ann Intern Med 2000;132:621-630. 